\title{
Holistic Thematic Learning in the Elementary School: Is It Thematic and Holistic?
}

\author{
Nurul Ain ${ }^{1}$ \\ ${ }^{1}$ Universitas Kanjuruhan Malang \\ Jl. S Supriadi 48 Malang, Indonesia
}

\begin{abstract}
The purpose of this study is to describe the holistic thematic learning at elementary school in the implementation of Curriculum 2013 in Indonesia: ie to know wether the learning is thematic and holistic. The research method used is descriptive qualitative. Data were collected through documentation, observation, and interviews. Data were analyzed based on Miles \& Hubermen interactive model. Conclusions are determined by triangulation of methods and sources. This study has two findings: 1) in preparing the theme networking, each subject indicator has not been associated with subthemes, 2) thematic learning is not designed holistically through cognitive, affective, and psychomotor aspects. Based on these findings it can be concluded that the implementation of Curriculum 2013 on thematic learning in Indonesia is not in accordance with the characteristics of a holistic thematic learning. It is not thematic and holistic. The results of the study imply that in designing the theme networking, the teacher should link the each subject matter with subtheme. Teachers must develop students' ability holistically on the cognitive, affective, and psychomotor aspects in a balanced.
\end{abstract}

Keywords: thematic learning; holistic; elementary school; curriculum 2013

\section{INTRODUCTION}

Elementary school students are generally between the ages of 7-12 years. Intellectual development of elementary school students are in the concrete operational level. At this stage, students begin to develop logical thinking, but still very bound by conceptual facts, it means it is still confined to real objects [1]. Another feature of the thinking stage of elementary school students are integrative and hierarchical thinking. Integrative means that students understand knowledge is an intact and integrated thing. Students have not been able to sort out the concept of the various disciplines. While hierarchical thinking means that students learn from a simple to the more complex concepts.

Learning which is in accordance with the elementary school students characters are thematic learning. Thematic learning is an integrated learning model that integrates multiple subjects in a single entity that is bound by the theme. The theme used as the bound between concepts, topics, and ideas of the course from one another [2]. As one model of integrated learning, thematic learning is a learning activity that combines a comprehensive and integrated knowledge that naturally connects facts and ideas in an 
attempt to understand the world. Thematic learning can increase students' score and motivation [3]. Thematic learning insists to inspire students' creativity, imagination, compassion, self-knowledge, social skills, and emotional health [4]. Learning thematic can also increase the scientific work of students [5], improving life skills [6], and increasing mastery of science concepts [7].

Students at these ages are still experiencing good growth physically, intellectually, and emotionally. The development speed of each student is varying, depending on their interaction with their family, school, and people around their house. Learning process must also develop the ability of students holistically in cognitive, affective, and psychomotor equally. Holistic learning cultivates a whole human being to understand the world [4]. Learning that emphasizes only the cognitive aspect and ignores the affective and psychomotor aspects causes the development process to be unbalanced [8].

Based on these discussions, the learning that suits the characteristics of elementary school students is holistic thematic learning. Implementation of thematic learning in Indonesia was started in the 2004 curriculum. It was done in grade 1 and grade 2. It was then refined in Curriculum 2006, which was implemented in grade 1 to grade 3 . After a few years, thematic learning in the 2006 curriculum has not been implemented [9-10]. The weakness was caused by teachers who do not understand concept of thematic learning.

In 2013, Indonesian government imposed curriculum 2013. Curriculum 2013 was made based on the evaluation of the curriculum 2006 implementation which only emphasized on the development of cognitive aspect, but it had not described aspects of attitudes, skills and knowledge holistically [11]. The feature of curriculum 2013 at the elementary level is a thematic learning done on grade 1 to grade 6 and learning which have to develop cognitive, affective, and psychomotor equally. So characteristic of Curriculum 2013 for elementary school is holistic thematic learning.

Two semesters after the implementation of Curriculum 2013, the Minister of Education issued a letter No. 179342 / MPK / KR / 2014, to stop the implementation of Curriculum 2013, except some pilot project schools. The dismissal decision by the Minister of Education was based on recommendations of Curriculum Implementation Evaluation Team, which results showed that preparatory curriculum 2013 was too fast that there were various conceptual and technical problems. Some of the conceptual problems are inconsistencies between ideas with curriculum design and disharmony with the idea of the contents of the book, while the technical problem was the lack of school readiness and teachers preparation in implementing the curriculum 2013.

Thematic learning had not been implemented in curriculum 2006, whereas in curriculum 2013, thematic learning is still conceptual problems. Only creative teachers can apply thematic lessons in the 2013 curriculum (Ain, et al, 2014), whereas the ability of elementary school teachers to apply thematic learning is still low [12]. This condition informed that the thematic learning on the curriculum 2013 implementation is still to be perfected.

Base of these conditions, the question is the implementation of thematic learning in accordance with the concept of curriculum 2013: thematic and holistic? This research is very important to know whether the implementation of thematic learning is in accordance with thematic and holistic criteria. If it is not revealed, the implementation of a curriculum doesn't reach the expectation and same with separated learning. The results of this study can be used as a basic to improve the 
implementation of Curriculum 2013, particularly in designing thematic learning holistic.

\section{Purpose of the Research}

The purpose of this study is to describe whether the holistic thematic learning at elementary school level in the implementation of Curriculum 2013 is thematic (all integrated subject related to the theme/subtheme) and holistic (develop all abilities' aspect of students holistically in cognitive, affective, and psychomotor equally). The research questions are formulated as the following: how the teachers plan and implement a holistic thematic learning. Planning a thematic learning analysed how teachers make the theme networking and how teachers develop lesson objectives in the cognitive, affective, and psychomotor aspects holistically, then it comparison with implement of the holistic thematic leaning in class.

\section{METHODS}

\section{Research Design}

This research used descriptive qualitative approach. This research was conducted by analysing lesson plans created by teachers (as reflected in the guide book for teachers) and observe the teaching and learning process in thematic learning classes at elementary school level with the natural background.

\section{Subject of Research}

The Subjects of the study is 8 teachers who were teach thematic learning in SDN Jember Lor 03 and SD Al Hikmah Surabaya, East Java Province, Indonesia. The study was conducted in the fourth grade at both schools. The research was conducted in October 2014 until February 2015.

\section{Data Collection}

This research data was collected through the observation of thematic learning in the fourth grade, with the sub-theme "Let love our environment". The teacher gives the lesson plan to the researcher before the learning starts. Researchers do check the compatibility between lesson studies with the implementation of thematic learning. Checking is more emphasized on thematic learning characteristics, the theme bound of each integrated subject. Checking is also done on the implementation of learning holistically concerning aspects of cognitive, affective, and psychomotor. If the researcher feels a mismatch it will be done in-depth interview on the problem. Thus, data collection techniques in this study are: 1) documentation, 2) observation, and 3) interview. 


\section{Data Analysis}

Data analysis is performed using interactive model [13]. Data analysis starts from data reduction, data display, and conclusion. The analysis is performed on data obtained from documentation, observation, and interview, through method triangulation. Triangulation is also done on different sources (source triangulation), ie 4 fourth grade teachers every school. Triangulation is done in an effort to increase the trust of research so that obtained conclusion that can be justified its validity.

\section{RESULT AND DISCUSSION}

\section{Theme Networking}

The link between the theme and the subjects matter described in the theme networking. Based on an analysis of the guide book for teacher, it does not theme networking but Basic Competence networking that link the subtheme to the basic competencies and indicators networking that link the subtheme to the indicators for each subject. One examples of Basic Competence networking for the sub-theme "Let Love the Environment" is presented in Figure 1.

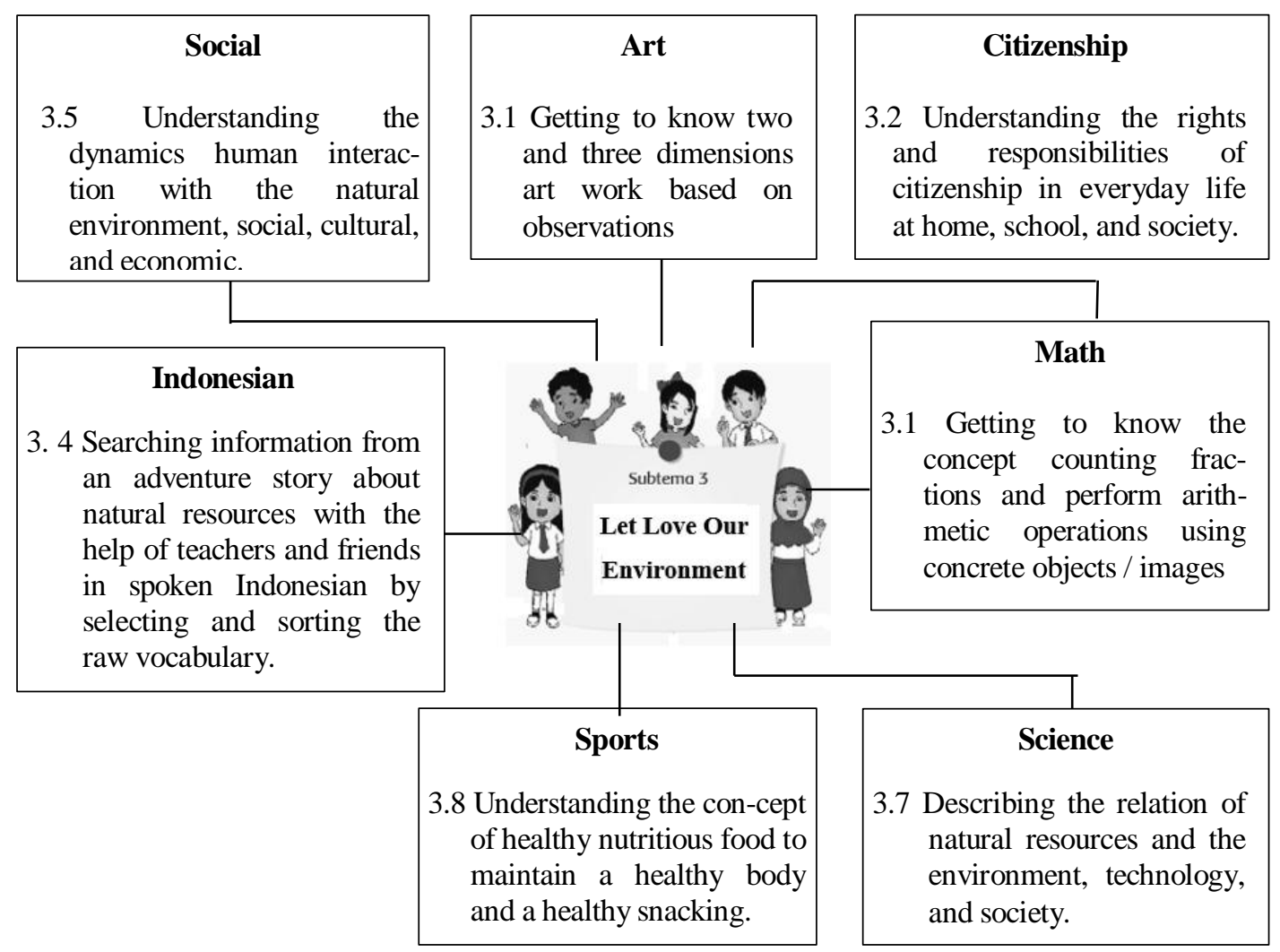

Figure 1. Basic Competence networking of theme 4 "Caring other Beings", subtheme 3 "Lets Love Our Environment", Class IV. 
Figure 1 shows that the invisible link between the sub-theme "Let Love our Environment" with the basic competence on each lessons. The figure also shows that Curriculum 2013 integrates all the subjects into themes/subthemes. The lessons are science, social, mathematics, Indonesian, citizenship, sport, and art. Integrating all subjects into theme/subtheme seems "forced" because some basic competencies do not have any link with subtheme. If a lesson cannot be linked to the theme/subtheme, the lesson should be taught separately.

In order to know the link of the theme/subtheme with every subjects matter, the analysis should be developed through indicators networking. The basic competence and indicators networking listed in guide books for teachers on thematic learning in Curriculum 2013. Unrelated basic competence with subtheme because the basic competence is a general competency that will be developed into indicators and learning objectives. For example, indicator networking of fourth grade on the theme 4 "Caring other Beings", subtheme 3 "Let Love the Environment", presented in Figure 2.

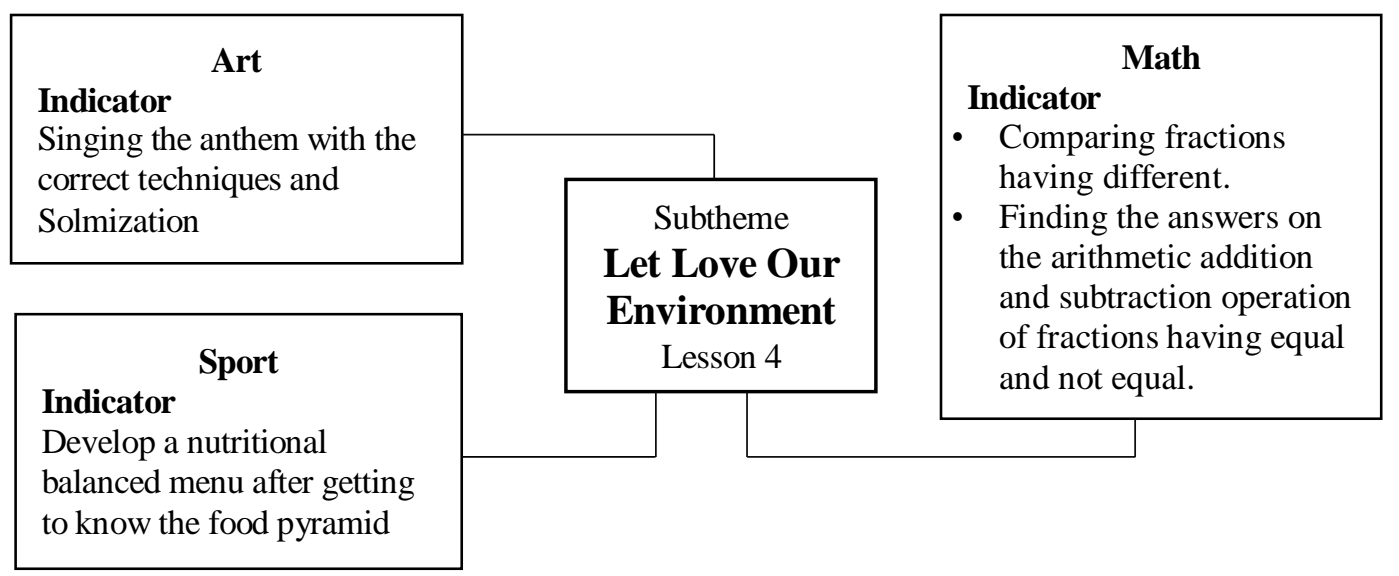

Figure 2. Network of indicators on Subtheme "Let Love our Environment", lesson 4, Class IV.

Figure 2 shows that the subjects integrated are art, mathematics, and sport. Based on Figure 1, the indicator of every lesson has not been associated with the subtheme. There was no link between the subtheme "Let Love our Environment" with indicators of art: "singing anthem with new techniques and correct solmization". There were no linked subthemes with sport indicators: "compiling menus nutritionally balanced after getting to know the food pyramid", and there was no link the subtheme with mathematic indicators: "arithmetic operations addition and subtraction of fractions having equal and not equal".

Researchers sought to find out how teachers arrange the network theme. Teachers A stated as follows:

"Sorry, I didn't teach them in accordance with the guide book, I am still trying to understand Curriculum 2013" (AG206).

The same was stated by teacher B as follows:

"Please give me any suggestion when you know that my teaching was not in accordance with the guide book" (AG104). 
From the statement of the teachers, the teacher started to try to teach thematic learning in accordance with guide book for teacher and student. Teachers do not understand how to put together thematic learning, determines the network of the theme of the chosen theme, as the result, anything in the guide book will be followed by teachers and taught to students.

Based on the description and analysis of the data of theme networking, data obtained from the documentation states that the indicator of every subject has not been linked to the theme and the data obtained from the interviews show that teachers teach in accordance with guide book, so the result indicates that each subject indicator has not been associated with the theme/subthemes.

The result of the study is the indicator for each subject has not been associated with the subthemes. This means that the implementation of thematic learning on the Curriculum 2013 has not yet matched the characteristics of thematic learning: ie theme/subtheme as linked to the integrated subject matter. Curriculum 2013 serves theme networking through the link basic competence and indicators with theme/subthemes. According to Fogarty (1991: 54) thematic learning integrates the subject matter, therefore the indicators is to be associated with the theme/subtheme.

The researcher develops interviews with teachers about the training of thematic implementation in the Curriculum 2013. Based on the interview, the training provides information to the teacher why the curriculum should change, what are the indicators, and how to use the guide book. The training does not teach how to design thematic learning, how to plan a theme network, how to develop the indicators that link to the theme, and how to develop the material, so researchers estimate that unrelated caused is because teachers do not understand the characteristics of thematic learning. Another thing that is thought to cause unrelated between indicators and subthemes, is a teacher determine Basic Competence and indicators directly from the theme/subthemes. In order to have a link between the subtheme and the subject matter of each subject, the teacher should explore the material linkage of each subject with the theme / subtheme.

Planning a thematic learning is complex and complicated activity, because they have to integrate some subjects as well as attitudes and skills related to the theme, by preparing the theme network. In thematic learning, theme plays an important role in linking each subject integrated with it. This is one of the characteristics of thematic learning. Material of each subject must be related to the theme / subtheme [2, 14]. The selection of a good theme allows students to explore concepts from various perspectives and viewpoints [15]. Theme as the connector between the lessons allows students to explore and understand the concepts of many different subjects. Teachers who have been trained in applying thematic learning will be more effective in meeting the needs of students [16-17] so inter-connection of the subjects with subthemes allows students to study more meaningfully.

\section{The Development Students' Abilities Holistically}

Students' abilities in the cognitive, affective, and psychomotor aspect can be seen in the developed of basic competence into indicators and learning objectives. Basic competencies in the Curriculum 2013 consist of basic competencies on the affective aspect: ie spiritual competence (BC-1) and social competence (BC-2), cognitive aspects (BC-3), and psychomotor aspect (BC-4). One example of Basic Competence development into indicators and learning objectives are presented in Table I. 
TABLE I. BASIC COMPETENCE DEVELOPMENT INTO INDICATORS AND LEARNING OBJECTIVES

\begin{tabular}{|c|c|c|c|}
\hline Subject & Basic Competencies (BC) & Indicator & Learning objectives \\
\hline \multirow[t]{6}{*}{ Science } & $\begin{array}{l}\text { 1.1 Increasing faith to God by } \\
\text { realizing the relationship of } \\
\text { the greatness of God toward } \\
\text { the order and complexity of } \\
\text { nature and the universe, and } \\
\text { practicing it in the teachings } \\
\text { of their religion. }\end{array}$ & & \\
\hline & $\begin{array}{l}2.2 \text { Appreciating the work of } \\
\text { individuals and groups in } \\
\text { their daily activities as a form } \\
\text { of implementation of carrying } \\
\text { out a review of natural } \\
\text { phenomena independently or } \\
\text { in groups. }\end{array}$ & & \\
\hline & $\begin{array}{l}\text { 3.8 Knowing the respiratory } \\
\text { systems of animals and } \\
\text { humans as well as diseases } \\
\text { related to breathing. }\end{array}$ & $\begin{array}{l}\text { 3.8.1 Know the organs } \\
\text { in the human } \\
\text { respiratory system. } \\
3.8 .2 \text { Explaining the } \\
\text { cause of the disturbance }\end{array}$ & $\begin{array}{l}\text { - By observing the image of } \\
\text { the human respiratory } \\
\text { organs, the students showed } \\
\text { the human respiratory } \\
\text { organs properly. }\end{array}$ \\
\hline & & respiratory apparatus. & $\begin{array}{l}\text { By finding out through } \\
\text { literature about diseases of }\end{array}$ \\
\hline & & $\begin{array}{l}\text { 3.8.3 Explaining some } \\
\text { diseases of the } \\
\text { respiratory apparatus. }\end{array}$ & $\begin{array}{l}\text { the human respiratory } \\
\text { organs, students can } \\
\text { mention the diseases in the } \\
\text { human respiratory organs } \\
\text { confidently }\end{array}$ \\
\hline & $\begin{array}{l}\text { 4.8 Presenting the reports of } \\
\text { illnesses associated with } \\
\text { disturbances in human organs }\end{array}$ & $\begin{array}{l}\text { 4.8.1 Creating reports } \\
\text { of illnesses associated } \\
\text { with disturbances in } \\
\text { human organs }\end{array}$ & \\
\hline
\end{tabular}

Based on Table I, the basic competencies development into indicators and learning objective is only be done on the BC-3 or only on cognitive aspects and on the part of the $\mathrm{BC}-4$ or psychomotor aspect. While affective aspect (BC-1 and BC-2) are not developed into indicators and learning objectives.

When researchers asked why the teacher did not develop the affective aspect (BC-1 and $\mathrm{BC}-2$ ), then the answer to the teacher $\mathrm{A}$ is:

The spiritual aspect taught in the religion lesson. Social aspect is observed during the learning takes place, whether the students pay attention or not, do chores, discipline, and others. (AG202)

BC-1 and BC-2 did not exist in the Lesson Plan because I adjust it to guide book. (AG203)

The results of interviews toward teachers show that affective aspects (BC-1 and BC-2) in the thematic learning at guide book for teachers also are not developed.

Based on the documentation data in the guide book it is found that the basic competencies on the affective aspects (BC-1 and BC-2) are not developed into the indicators and learning objectives. Data obtained from interviews stated that teachers 
did not develop affective aspect because in the guide book for teacher are also not developed. There is a match between the data obtained from the documentation and the interviews, so the results is thematic learning is not planned holistically involving the development of cognitive, affective, and psychomotor.

This result of the study is not yet integrated holistically the aspects of cognitive, affective, and psychomotor. The teachers tend to develop cognitive aspect only. These results indicate that thematic learning in the implementation of the curriculum 2013 is not yet holistic. The development of basic competencies into indicators and learning objectives must be done to all aspects. The development of Basic Competence into all aspects will ensure the achievement of competence specified and all students' ability developed holistically.

The link between the three aspects is very closely and its development cannot be separated. The values learned on the cognitive aspect will affect attitudes and behaviours so that students will become complete human beings [18]. It is not only the intellectual aspect that needs to be developed but also physical, social, moral, aesthetic, creativity, and spirituality [19]. The lesson which is not done to develop the three aspects led to the students' development is unbalanced and incomplete. Therefore, the three aspects are very important to influence the behaviour of a person. The development of all aspects of students' abilities will generate a holistic human being.

Several studies have shown a positive influence of holistic learning implementation towards education. Student that implements a holistic education will have a higher score on characters and the multiple intelligences [20]. The integration of character values in learning Mathematics and Science sufficiently effective to be developed in learning [21]. Learning outcomes of the three aspects will determine the success of the student when they are adult [22]. People with a high level of spiritual intelligence have a higher entrepreneurial attitude compared with the people who have a low level of spiritual intelligence [23]. The results of these studies inform the importance of developing the three aspects holistically.

\section{CONCLUSIONS}

The results of the analysis of the lesson plan, guide book for teacher, and teaching observation has two findings: 1) in preparing the theme network, indicator of each subject has not been associated with the theme / subthemes, and 2) thematic learning is not planned holistically involving the development of cognitive, affective, and psychomotor. These findings are the weakness guide book on the implementation of Curriculum 2013. These findings indicate that the guide book prepared to meet Curriculum 2013 is not suitable with the characteristics of a holistic thematic learning. If the characteristic is not fulfilled, thematic learning seems as a separated learning and only develops cognitive aspects. Based on these findings it can be concluded that the thematic learning in the implementation of the curriculum 2013 has not been thematic and holistic.

Based on the findings described above, it is suggested to the teacher or team of guide book developers as follows: 1) in planning the theme networking, we recommend teachers to analyse and explore each of the subject matter that related to the theme / subtheme, then develop Basic Competence in two indicators of integrated subjects. 2) Teachers should develop all aspects of the students' ability both in 
cognitive, affective, and psychomotor, and the implementation is integrated into the material of a lesson.

\section{ACKNOWLEDGEMENTS}

Our thanks to the principal, teachers, and students of SDN Jember Lor 03 and SD Al Hikmah Surabaya, on their willingness to be the place and subject of research.

\section{REFERENCES}

[1] Slavin, R. E. (2006). "Educational Psychology: Theorv and Practice". Eight Edition. New York: Pearson.

[2] Fogarty, R. 1991. "How to Integrate the Curricula". Palatine. Illinois: IRI/ Skylight Publishing, Inc.

[3] Liu, M. C. and J.Y. Wang. 2010. "Investigating Knowledge Integration in Web-based Thematic Learning Using Concept Mapping Assessment”. Educational Technology \& Society. 13 (2): 25-39.

[4] Miller, R. (2005). "Philosophical Sources of Holistic Education". Turkish journal Deðerler Eðitimi Dergisi (Journal of Values Education). 3 (1).

[5] Pitadjeng. 2009. "Peningkatan kerja ilmiah siswa kelas II SD dengan Pengembangan Pembelajaran Tematik". Jurnal Kependidikan. 39 (2): 87-94.

[6] Rede, A. (2010). Pengembangan perangkat pembelajaran tematik pokok bahasan pemanasan global dan pengaruhnya terhadap kecakapan hidup, motivasi, dan prestasi belajar siswa SD di Karangploso. Disertasi doctor tidak dipublikasikan. UM.

[7] Hendrawari, S. 2010. "Penerapan model pembelajaran Tematik Tipe Spider Webbed untuk Meningkatkan Penguasaan Konsep IPA Siswa Kleas II SD”. Jurnal Studi Agama dan Masyarakat. 7(2): 108-153.

[8] Bose, K. 2010. Holistic Development of Young Children in ECE Centres of Botswana. International Academic Journal of Social Sciences, 3(10): 19-27.

[9] Akbar, S., W. Sutama, Pujianto. 2009. "Pengembangan Model Pembelajaran Tematik untuk Kelas I dan Kelas 2 Sekolah Dasar". Jurnal Penelitian Kependidikan. 1(2): 140-151.

[10] Ain, N., M. Kurniawati. 2013. Implementasi Kurikulum KTSP: Pembelajaran Tematik di Sekolah Dasar. Jurnal Inspirasi Pendidikan. 3(2): 316-328.

[11] Sisdiknas. (2012). "Uji Publik Kurikulum 2013: Penyederhanaan, Tematik-Integratif". www.kemdiknas.go.id/kemdikbud/uji-publik-kurikulum-2013-1.

[12] Murdiono, A., Gipayana, G. and Madyono, S. 2016. Developing of Integrated Thematic Learning Model through Scientific Approaching with Discovery Learning Technique in Elementary School. International Academic Journal of Social Sciences. 3(10): 19-27.

[13] Miles, M. B. and Huberman, A. M. (1994). An expanded sourcebook: qualitatif data aAnalysis. Second edition. London: Sage Publications.

[14] Jacobs, H. H. 1989. Interdisciplinary curriculum: design and implementation (USA: ASCD) pp 54-59

[15] Davies, M. and R. S. Brown. 2011. "A Programmatic Approach to Teaming and Thematic Instruction". Nort Carolina Middle School Association Journal. 12(1): 1-17.

[16] Min, K.C., A.M. Rashid, and M.I. Nasri. 2012. "Teachers' Understanding and Practice towards Thematic Approach in Teaching Integrated Living Skills (ILS) in Malaysia". International Journal of Humanities and Social Science. 2(23): 273-281.

[17] John, Y. J. (2015). A "new" thematic, integrated curriculum for primary schools of Trinidad and Tobago: A paradigm shift. International Journal of Higher Education. 4 (3), 172-187.

[18] Unesco-Apnieve Sourcebook No. 2. (2002). "Learning to be: A holistic and integrated approach to values education forhuman development: Core values and the valuing process for developing innovative practices for values education toward international understandingand a culture of peace". Bangkok: UNESCO Bangkok.

[19] Mahmoudi, S., E. Jafari, H.A. Nasrabadi, and M.J. Liaghatdar. 2012. "Holistik Education: An Approach for 21 Century”. International Education Studies. 5(2): 178-186. 
[20] Latifah, M., and N. Hernawati. 2009. "Dampak Pendidikan Holistik pada Pembentukan Karakter dan Kecerdasan Majemuk Anak Usia Prasekolah”. Jur. Ilm. Kel. dan Kons. 2: 32-40.

[21] Hudha, A.M., D. W. Ekowati, and Husaman. 2014. "Character education model in mathematics and natural sciences learning at Muhammadiyah Junior High School”. International Journal of Education Learning \& Development. 2(4): 33-47.

[22] Haji, J., A.B. Bemby, and I. Sentosa. 2013. "The Intelligence, Emotional, Spiritual Quotients and Quality of Managers". Global Journal of Management and Business Research. 13(3.1.): 1-12.

[23] Masoud, T. L. and A. Elaheh. 2012. "Spiritual Quatient and Entrepreneurship (A Case Study)". Interdisciplinary Journal of Contemporary Research in Business. 4(5): 881-891.

[24] Ain, N., Prabowo, Suparman. 2014. "Guru Kreatif Kelas IV SD, Tema "Selalu Berhemat Energi": Implementasi Kurikulum 2013”. Prosiding Seminar Nasional Pendidikan Sains Unesa. Surabaya.

[25] Chen, Y. T. 2012. "The effect of thematic video-based instruction on learning and motivation in e-learning". International Journal of Physical Sciences. 7(6): 957 - 965.

[26] Kemdikbud. 2014. Buku guru SD/MI Kelas IV: Peduli terhadap makhluk hidup. (Jakarta: Kemdikbud). P. 99. 